\title{
Women's Substantive Role In Local Government Khyber Pakhtunkhwa: Challenges And Opportunities
}

\author{
Latif Ullah \\ \& \\ Khalil Ahmad \\ Department of Sociology, Institute of Social \& Cultural Studies \\ University of Punjab
}

\begin{abstract}
Women's socio-political interests are largely related to their political representation. But the debate goes around their descriptive and substantive representation. The later representation is deemed to be more effective in addressing women issue. The present study was an attempt to analyse women's substantive role in local government Khyber Pakhtunkhwa with a focus upon challenges confronting their role and potential opportunities for being part of political system in local government in (KP).The study was conducted in district Mardan Khyber Pakhtunkhwa. Ten in-depth interviews were conducted with women councillors elected on reserved seats in village/neighbourhood council of district Mardan by using purposive sampling technique. Women's participation in local business, women's influence on political party, women's access to local government financial resources and women's role in civil society's mobilization were covered under women's substantive role. Respondents' views were analysed against the backdrop of underscored themes.
\end{abstract}

Keywords: Women's Substantive Representation, Challenges, Opportunities, Council's Business, Financial Resources, Mobilization.

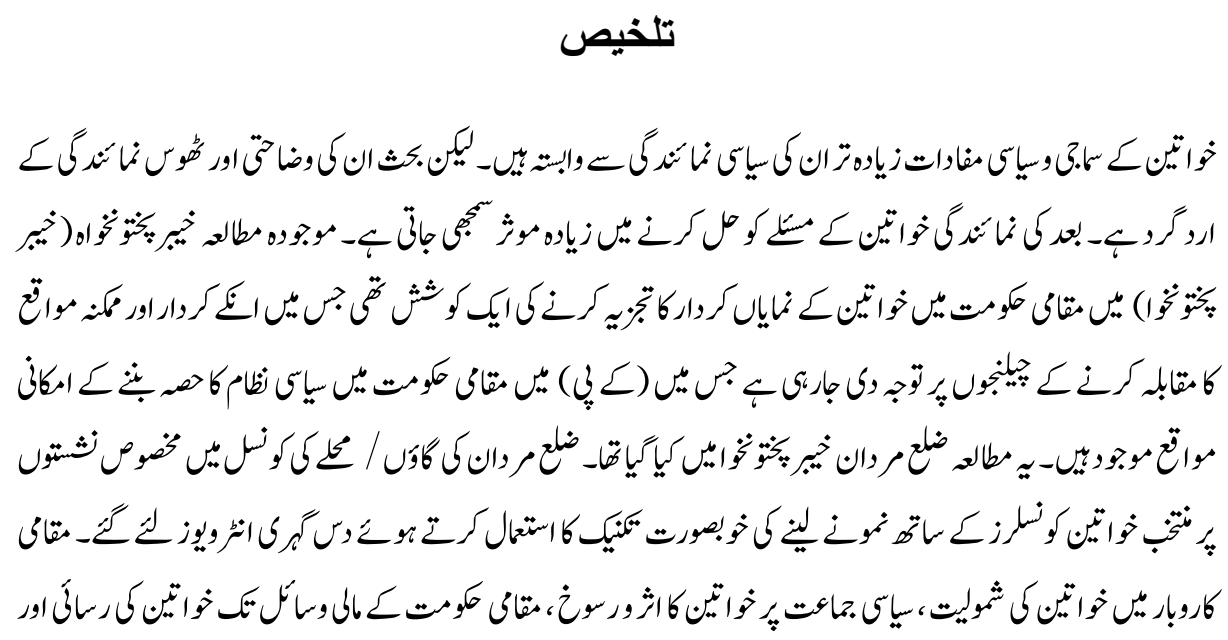




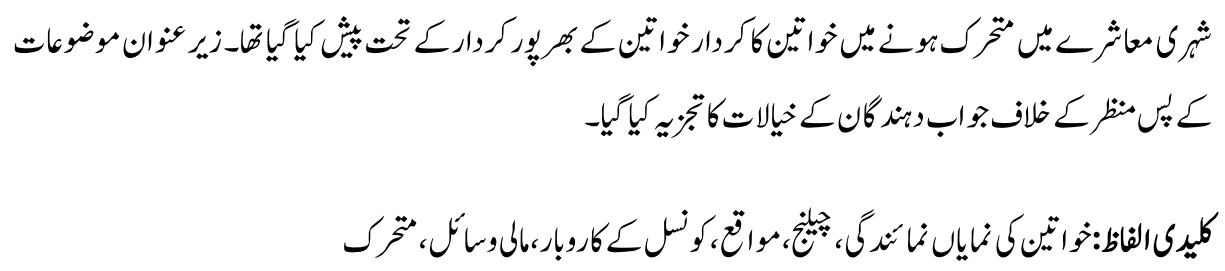

\section{Introduction}

Women's political representation is categorized into three types as formal, descriptive and substantive (Paxton, 2006). The most attractive debate of feminist scholar regarding this categorization is distinction between descriptive and substantive representation; whereas substantive representation "acting in the interest of the represented, in a manner responsive to them" (Koyuncu, 2016) is valued over descriptive representation, "standing for a group by virtue of sharing similar characteristics such as race, gender, ethnicity; not acting for them" (Koyuncu, 2016).

Women politicians possess various ethnic, racial, religious and ideological backgrounds as well as they are belonging to different classes and castes (Yuval-Davis, 2006). The question rose due to the increase in number of women in politics whether this increase encourage selected women to play their role in policy level initiatives (Arnesen, 2019). An extensive research is conducted in politically advance countries for addressing women's unproductive role in politics; however the research work about under debated issue in developing countries including Pakistan is minimal. The initiative been taken by Pakistan, to engage women in local politics as to participate in local bodies is encouraging for strengthening women voice (Gine, 2011). Women's participation and representation in politics is major component to their empowerment. The government of Pakistan made various legislations for women's political engagements to overcome women's community problems at grass root level and more importantly to empower them socially, economically and politically. The Khyber Pakhtunkhwa Local Government Act, 2013 (Local Government Department, 2013), was passed by the Provincial Assembly of KP (Buneri, 2013) generally follows the provisions of the North-West Frontier Province Local Government Ordinance, 2001, which had come into force on the 14th day of August, 2001 (Since repealed by the Local Government Act, 2012 in Province). Khyber Pakhtunkhwa local government act 2013 defined the structure of local bodies; in every district; the top tier is called district council, the second tier is tehsil council and in the gross root tier of the local bodies is village/neighbourhood council (Buneri, 2013). Beside the structure the procedure of election is also defined in Khyber Pakhtunkhwa Act, 2013. In the lowest tier all the members including general councillors, women, minority, peasant and youth 
councillors are directly elected from the vote of the general public. The candidate who secured highest score of vote is automatically declared as chairman and the second highest candidate is called vice chairman. In village/neighbourhood council women are elected on two reserve seats. In the act various role and responsibilities are assigned to all the members of the council including monitoring of government departments working in the council area, they are assigned the role to identify people needs, propose needs to council for further submission to upper council. The council members are provided the opportunity to develop plans for developmental work in the council area and make sure the registration of marriage, birth and death (Article 29 (1) of local government act, 2013 Khyber Pakhtunkhwa). The council is responsible for helping the district and tehsil governments in conduction of various researches and survey planned in the council area (Article 29 (2) of Local Government Department, 2013).

Politics in Khyber Pakhtunkhwa is always considered as men's job, thus it is difficult for women to survive in politics. Women in Khyber Pakhtunkhwa lack women mobilization networks, lack political understanding and exposure (Saeed, 2019). Taking part in politics for women is considered stigma, as a result women political workers are discouraged for their activities. Patriarchy is entrenched in politics directed by Pukhtunwali (Naz, 2011). Hence women's participation is seen as gift rather than a right, which undermines the respect they have earned in their own right to be elected to positions of leadership (Chhibber, 2002). Women find it hard to participate in politics because of their burden of domestic responsibilities assigned to them by their respective families (Bari, 2005).Women have no or very little time to participate in politics (Naz, 2012). Besides this, women are also restricted by their respective families to interact with male and join public meetings (Bhatla, 2012).

Moreover, women been engaged to politics was also opposed by their respective political parties. Usually party meetings' timing and venue were not suitable to women. Political parties deliberately humiliate and frustrate women into losing focus and excluding them from active participation in politics (Garboni, 2015). Women are usually not elected at the position of power within the party structures because of gender biases of male leadership (Shah, 2015). Often male dominated political parties have a male perspective on issues of national importance that disappoints women as their perspective is often ignored and not reflected in the politics of their parties (Ahmed, 2013). Political structure is not friendly to women engaged to politics as a result women are exploited from their political rights (Goetz, 2003). The limited numbers of women in politics, make it more difficult for elected women to push their interest in appropriate forums (Krook, 2010). In countries where the majority numbers of the leaders are male, lobbying for securing women interest becomes very difficult (Khan, 2006). Women in Khyber Pakhtunkhwa are not only facing challenges as elected representatives rather, they are facilitated too with considerable opportunities in local bodies. They can avail this facilitation through their 
active political participation in the local bodies' council affairs (Saeed, 2019).The local bodies system can be used as a source for women public sphere engagement, learning and capacity building. Further women councillors are provided the opportunity to organize and develop networks of women for women rights protection and mainstreaming in political, economic and social spheres (Khan, 2009).Keeping in view, the substantive role of women elected on reserved seats in the local government Khyber Pakhtunkhwa, this study is designed to analyse the challenges and opportunities to women's substantive role in local bodies Khyber Pakhtunkhwa.

\section{Review of Literature}

Women's subordinate position with respect to men is a global issue, though its nature and extent is changed from country to country. Gender role ideology is not associated with masculinity or femininity only, it also place women in inferior position. Female sex is not valued in public sphere due to women's reproductive role. People assume from women to live inside the four walls of their home. Their outdoor movement was monitored by their respective families. As a result, their engagements to political activities are considered as stigma for their respective families (Saeed, 2019). The mechanisms of sex segregation and purdah are used to restrict their mobility. Politics requires women's exposure to interact with male and female constituents and address public meeting (Zakar, 2018). Women are exploited by various tactics, no or very limited resources were allocated to women's human development by the state, society and the family (Shvedova, 2005). Even women being elected as women representative in politics were unable to represent women interest effectively (Gopalan, 2012). They were incapable to overcome socio cultural challenges. "Women are overburdened with different household activities impeding their involvement in the politics of the country. Illiteracy and ignorance of women folk regarding their rights and duties in relation to politics hinder women's political empowerment"(Khan, 2009). Women in Pakhtun society are still not facilitated with National Identity Cards; some of them are not register in voter lists while the registered women also faced with the same situation and could not participate in the election process because of the distant polling stations.

Although the literature support that women's contribution to the development of society is higher than that of men because of their dual role of production in economy and reproduction in family. While, their participation in political activities is insufficient as compare to men (Kasapoglu, 2011). According to United Nations resources (UNDP, 2005), "the proportion of women representatives in the political arena worldwide is only $15 \%$ ". Despite high levels of commitment to gender equality on the part of international agencies watched by the Convention on Elimination of All Forms of Discrimination Against Women (CEDAW), desired changes still fall below the expected rates. Women's political participation is the key remedy to overcome the issue of women exclusion from 
public sphere. In this context there are two basic arguments: intrinsic and instrumentalist (Kasapoglu, 2011). "The intrinsic argument refers to human rights in terms of democracy and the proportion of the female population, which is half that of the total world. On the other hand, the instrumentalist argument mostly focuses on the differences between men and women" (Kasapoglun, 2011). Since women hold different values and views regarding politics, they bring special and unique implications for politics hitherto missing (Kasapoglu, 2011).

Women's equal representation in politics is criticised by various feminist scholars, as a result they divided the term into three main broader concepts called perspectives of women representations. Those are as: formal representation of women, descriptive representation of women and substantive representation of women (Paxton, 2007). The formal representation perspective urged that women should have equal representation as men are representing in politics; (Nazneen, 2018) this is the legitimate right of women to be represented equally in the every aspect of societal matter. They emphasised that all the obstacles which hindered women equal representation should be discourage and rejected (Ocran, 2014). Both men and women are given political right to take part in the election process they should cast their vote, take decisions, and take part in the election campaigns and to be elected as a candidate (Paxton, 2007). This type of women representation in politics is secured by the Beijing declaration in 1995 as "No government can claim to be democratic until women are guaranteed the right to equal representation" (United Nations, 1995). The formal representation of women is criticised by feminist political philosopher due the underrepresented status of women in politics (Ocran, 2014). Majority of the state throughout the globe have given women to the formal representation status but still women are not taking part in politics as men, only a very few states have more than 22\% women representation in their politics (Paxton, 2007). As a result this failure gave birth to another debate, that men should be represented in the politics as per their numerical presence, if women have $50 \%$ population, it is needed to have $50 \%$ representation too in every sector of the society (Ocran, 2014). Literature stated that men and women are not considered same in the political sphere and their interest is different (Kassa, 2015). Therefore, women by their own selves must be visible in the political domain as well as in other sectors of the society too (Ngara, 2013). The Descriptive approach has some positive influence on women excluded status, women got more representation in every field and they get chances to overcome those societal factors, which promote women exclusion from public life. Women get representation in political parties, education and health; their numerical number improved at some level and makes it easy for women to engage to the public sphere (Reyes, 2002).

Before, discussing substantive representation in the light of literature, first it is needed to mention here the criticism of some feminist Scholars on women's descriptive representation (Shvedova, 2005).As there are various scholars, they oppose to women's 
descriptive representation, they raised question regarding the role of women they performed being representing the excluded segment of the society (Tefera, 2010). They questioned as did women on the basis of similar gender characteristics act for general women's interest? It was urged, that all women are not equal; they have different socialization background, different level of opinions, representing different ethnic group and different interests. They do not have the common agenda to secure women interest (Goetz, 2003). Substantive representation follower emphasised that there is difference in standing for and acting for, standing for cannot be same as acting for (Ocran, 2014).

The substantive perspective get stand on that "a growth of women's representation in parliament would make a substantive difference due to the fact that women and men carry different experiences and priorities when considering political issues" (Umer, 2016). Women are represented for protecting women interest, that interest would not be one's individual that would be common for all women. Women should represent all those issues in the political forums which lead women marginalization in the society. The question rose regarding women 'substantive representation as that to what extent women elected representatives on behalf of their excluded women influence government and other official to overcome women poor representation. It is often consider that women numerical representation would bring improvement in women's status. But the facts and figures regarding women status are not encouraging in this regards (Ahebwa, 2009).

It is crucial to inquire whether women councillors in local bodies Khyber Pakhtunkhwa act as agents of change or just members to the council to fulfil the local government system's formality (Zakar, 2018). It is needed to inquire that to what extent women elected representative influence the council agenda for women interest being a representative of the local government. How much they get support of their male colleagues to strengthen their voice for women access to education and health.

\section{Research Methodology}

This study adopts the qualitative research approach to inquire challenges and opportunities of women elected representatives in local bodies Khyber Pakhtunkhwa with respect to their substantive role. The qualitative method of research is based on interpretative approach; it suggests understanding the reality from the perspective of those who involved to the situation (Ormston, 2014). As a result women elected representatives' actual experiences about their role in local bodies were analysed in the study. The study was conducted in district Mardan, Khyber Pakhtunkhwa; As per Local Government Act 2013 Khyber Pakhtunkhwa two seats were reserved for women in every village/ neighbourhood council. Women elected on reserved seats in village/ neighbourhood council of the district Mardan, Khyber Pakhtunkhwa were selected as 
study respondents. The purposive sampling technique of qualitative research method was used to collect study data. It is suggested in qualitative research, that the interviewees were not selected randomly; rather, the choice was dictated by convenience and availability of the respondents (Teddlie, 2007).

The principal author conducted 10 in-depth interviews with study respondents to assess their substantive role in local bodies. Women's substantive representation in local government Khyber Pakhtunkhwa was covered by four pre developed themes as; women's participation in the council business, Women's influence on political party, women's access to local government financial resources, and women's role in civil society's mobilization. The researchers further asked leading questions under each theme to collect data with respect to challenges and opportunities to women substantive role in local government Khyber Pakhtunkhwa. The study suggests open ended questions to allow the participants to fully describe their experiences from their own view point.

To ensure the ethical consideration, the researchers took verbal consent from the respondents and assured them that the study is conducted for academic purpose; all of information will be kept in secret and would not be disclosed.

\section{Results}

Qualitative Description

The focus of the analysis was to explore the emerging themes and understand the life experiences of women councillors with respect to challenges and opportunities to their role in politics. As a result, the findings were not presented numerically.

\section{Women's Participation in the Council Business}

The idea that one or few women are important to push women's issues can be as important as having a critical mass. The concept of policy entrepreneurs are closely related to the substantive approach (Blomgren, 2010). Women are the elected representative they can take participation in the council business as men. The study participants were asked at "what extent you would take part in the council agenda?" One of the participant responded to the question as;

"Being a councillor I take part in council's meeting but I faced with some challenges when I try to incorporate own point of view in the meeting agenda. Actually the secretary to local government council has the authority to incorporate one point in the council agenda. Usually, men 
councillors influenced him for avoiding women' point of view incorporation in the council agenda".

The respondents were asked that "do you find any support from men's councillors to initiate policies with respect to women access to education and health?" The respondents replied as;

"The council support us to take part in the meeting discussion when the discussion is about women issues; the men councillors support us in identifying effective strategy to overcome the issue of women lack of access to education and health".

The local government council consist of men and women councillors as both have equal opportunity to the membership of council committees, the local council have certain committees, as public account committee, ethic committee, local development projects monitoring committee and local dispute solution committee (local Government 2013, Khyber Pakhtunkhwa). The women councillors were asked to find out their access to the membership of local council's committees as "do you have access of membership to the committees working under the supervision of the local government council?" The respondent shared her experiences regarding access to representation in council's committee as;

"Women do not have equal access to become member of every committee as men. But there are few to which we are member. I am member to the local development project monitoring committee of the local council. I am actively engaged to monitor the projects related to women education and health. I coordinate with the local community, if there is any deficiency in the project implementation; I report it to the local council and influence the council to initiate strategies to overcome the deficiency".

The question was asked from the study participants that "to what extent you are satisfied with your present status?" One of the respondent replied as;

"Women reserve seats representation is the best strategy to represent women in the local politics, she added that majority of women are new, they were elected first time to this council, and as a result they lack political understanding with respect to represent women interest effectively. She added that some of men councillors discourage women's reserved seat representation; they consider women reserved seat representation as gift of men to women". 


\section{Women's Influence on Political Party}

It is reasonable to argue that if more women are members of decision making organs within parties that elect candidates for election, more female candidates will be elected. Being a political worker woman can influence the party policies to hold the position of power and represent women's interest in the party political events.

The study respondents were asked as "being a political worker can you influence your affiliated political party's policies with respect to take part in the election process?" the study participants responded as;

"In the last election women participated in the party election campaigns, they mobilized women to cast their vote in the election. The party policy however was against with respect to women engagement to the election campaign but women campaign was more effective than men. Being women we visit door to door in the constituency by using the limited financial resources".

The respondents were asked about their influence on party policy to hold the position of power and contest election as a candidate. They responded as;

"Some of our women enjoy the power position in the party, but we failed when we demand for party ticket to contest election as a candidate. The men party workers justify their opposition by saying that the public do not vote women candidate as the public assumed that women could not represent the constituency effectively."

\section{Women's Access to Financial Resources of Local Government}

In local government act, 2013 the local council is legally empowered to develop their budget (KPLGA, 2013).This makes capable the council to mobilize the local resources and design development project to solve issues at grass root level. The study participants were asked about their role regarding designing projects with respect to women access to education and maternal health, and their influence on council to incorporate gender responsive projects in the council budget. One of the respondents shared her views as;

"We are capable to design gender responsive projects, in this regards the local government secretary and some men councillor support us but actually we faced with the issue that our numerical representation in the council is very less as compared to men as a result our projects are not incorporated in the council budget". 
The respondents were asked about their shares in local government fund as that "do you utilize your own shares of local government fund for improving women access to education and health". The respondent shared their view regarding it as;

"Our share in the local government fund was given to our family members instead of us, the men councillors convince our male family's members that it will be better to utilize women councillors' fund for the general local need".

\section{Women's Role in Civil Society's Mobilization}

Women's councillors are being responsible to organize the local community with respect to women voice strengthening, being political workers; they are responsible to develop women networks and lobbies to establish pressure on government to overcome women issues. The respondents were asked for their role as to "what extent they organized the local community to strengthen women voice and make lobbying for women access to education and health? One of the respondents replied to the question and shared her view as;

"Yes, being councillors, we are closely touched with the available women organization and also we have initiated various strategies to sensitize the local community women for their right as access to education and health".

The question was asked from the respondents that "do you mobilize the local organization to convince women for taking part in the election process as vote casting? One of the respondents replied that;

"Undoubtedly, being political activist we mobilize the community to cast their vote, we get support from the women organization in this regard to sensitize the women for the importance of vote. She added being political workers; we report those actions which have been taken against women vote casting"

\section{Discussion and Conclusions}

The study observed that women elected on reserved seats were aware about their role in local bodies, but they are incapable to manage the potential opportunities to overcome challenges they faced during representing women interest in local bodies (Chhibber, 2002). This lower level of participation is not only a consequence of the resources that women possess but due to their lack of confidence (Chhibber, 2002). It is surprising that the intensity of elected women on proposed policy initiatives in local bodies remain low. Even women have a good education and political background could not act as agent of change due to their insufficient number in the council and lack of political understanding and exposure. Their view point is often ignored in council business by their male counterpart, moreover, women councillor who lack political understanding are unable to take part in the council agenda (Shvedova, 2005). The most significant finding of this 
study is that women reserved seats representation make them dependent on men, they believed that our present status is gifted by men. They do not claim their present status as right, as a result they obeying male dominancy and failed to secure women interest effectively. Women who can negotiate independent space for themselves are more likely to be active participants in the political process.

The government of Khyber Pakhtunkhwa encouraged women to take active part in local council politics but they are discouraged by their cultural, social and economic factors. Those women who become members of local council faced challenges from their male colleagues in active participation in the council affairs (Gopalan, 2012). In the province particularly the political sphere is hold by men and social norms encourage male dominancy in political institutions (Saeed, 2019). Beside it there are some opportunities for women councillors in local bodies. Ahebwa (2009) indicates that "legal and institutional framework and empowerment of women organization are some of the opportunities available for women. Also, some women leaders are found to be promoting the interest of women and striving for social justices through the village court" (Ahebwa, 2009). To overcome socio cultural barriers to women political participation women organization and networking are needed. Women elected representative can act as a mobilizer to push women interest by strengthening their voice (Ocran, 2014). Differences between men and women also appear with respect to the content and priorities of decision making, which are determined by the interests, backgrounds and working patterns of both sexes. Women tend to give priority to societal concerns, such as social security, national health care and children's issues and access to education. The study added that women being elected as representatives faced with difficulties, they declared that they were influence by men's councillor with respect to the incorporation of women development projects in the local council budget.

The selection and nomination process within political parties is also biased against women (Zakar, 2018). The study respondents added that they were ignored by their political party with respect to the election contesting as a candidate. While the study respondents' highlighted that women being a political worker can take part in the party election campaign to represent women interest in party events. The study explored that women are not represented equally as men in local government committees, however the level to which they are represented in the council committee, they represent women interest effectively. Women have the legitimate right to contribute to politics on the same level as men (Ocran, 2014). Women must have the power to cast ballots and the prerogative right to contest in elections as well as biasedness that do not serve the interest of women in the political sphere be removed (Paxton, 2007), The present study added to this view as that being councillors they can initiate strategies with the coordination of women rights activist to sensitize women for the importance of women 
vote, and added that they can take actions against those who banned women involvement to the election process by organize way. The present study concluded that representation on reserved seats with in the available male dominated political structure creates considerable challenges to women to represent women interest at grass root level in local government.

\section{Recommendations}

i. Civil society and women activist need to initiate advocacy campaigns with respect to the women sufficient numerical representation in the local government.

ii. Women need to win the support of their fellow women, families, clans and friends in the political race

iii. The local councillors must realize the need of unity and cohesion for a common goal, as women access to education and health

iv. Women councillor should be committed to their political role, they have to influence the council for attaining their shares in local government fund to get economic power.

v. Women councillors should initiate lobbies to get the support of men councillors with respect to the women development project incorporation in the council budget

\section{References}

Agbalajobi, D. T. (2010). Women's Participation and the Political Process in Nigeria: Problems and Prospects. African Journal of Political Science and International Relations, vol.4:2, pp.075-082.

Ahebwa, A. (2009). Challenges to Women's Participation in Local Council Elections in Uganda: A Case Study of 1997 and 2006 Elections in Mityana District (Doctoral dissertation, Makerere University). Retrieved from https://pdfs.semanticscholar.org/ 7d1a/c32aaefb1652d1fa2108420955cb2ae72eeb.pdf

Ahmed, S. (2013). The Cultural Politics of Emotion. Routledge. Retrieved from https://pdfs.content.taylorfrancis.com

Bari, Farzana (2005). Women's Political Participation: Issues and Challenges (United Nations: DAW, Expert meeting group, Bangkok, Thailand, 8-11 Nov. P.1 retrieved from https:// pdfs.semanticscholar.org 
Bhatla, N., Walia, S., Khanna, T. \& Verma, R. (2012). Opportunities and Challenges of Women's Political Participation in India: A Synthesis of Research Findings from Select Districts in India. International Centre for Research on Women (ICRW)United Nations Entity for Gender Equality and the Empowerment of Women (UN Women) Joint Publication. Retrieved on March 01, 2019 from https://pdfs.iknowpolitics.org > sites > files > india_governance_report_synthesis_2013

Blomgren, E. (2010). Women and Political Participation: A Minor Field Study on Hindrances for Women's Political Participation in Georgia. Retrieved from https://pdfs.diva- portal.org

Buneri, S. (2013). Taliban Militancy: Replacing a culture of Peace. Tigha, a Journal of Peace and Development. Retrieved on April 14, 2019 from https://frc.org.pk > wp-content > uploads > 2013/07 > 4.pdf

Chhibber, P. (2002). Why are Some Women Politically Active? The Household, Public Space and Political Participation in India. International Journal of Comparative Sociology, vol.43:3-5, pp.409-429.

Garboni, E. S. (2015). The Impact of Descriptive Representation on Substantive Representation of Women at European and National Parliamentary Levels. Case Study: Romania. Procedia-Social and Behavioral Sciences, vol.183, pp.85-92.

Gine, X. \& Mansuri, G. (2011). Together We Will: Experimental Evidence on Female Voting Bbehavior in Pakistan. The World Bank. Retrieved from https://pubs.aeaweb.org > doi > pdf > app.20130480.

Goetz, A. M. (2003). The Problem with Patronage: Constraints on Women's Political Effectiveness in Uganda. No Shortcuts to Power: African Women in Politics and Policy-Making, New York, pp.110-139.

Gopalan, J. (2012). Women in Politics in South Asia. Prajnya Resource Centre on Women in Politics and Policy, Background Paper Series, (1).

Kassa, S. (2015). Challenges and Opportunities of Women Political Participation in Ethiopia. Journal of Global Economics, vol.3:4, pp.1-7.

Kasapoglu, A. \& Özerkmen, N. (2011). Gender Imbalance: The Case of Women's Political Participation in Turkey. Journal of International Women's Studies, vol.12:4, pp.97-107. 
Khan, A. (2009). Barriers to the Political Empowerment of Women in Dir Lower. Retrieved from https://swgi.lums.edu.pk > default > files > user376 > asif_khan__panel_7

Khan, M. R. \& Ara, F. (2006). Women, Participation and Empowerment in Local Government. Government Act-2013. Retrieved on March 05, 2018 from http://lgkp.gov.pk/wp-content/uploads/2013/12/Local-Government-Act-2013.pdf

Khyber Pakhtunkhwa Local Government Department.(2018). Khyber Pakhtunkhwa Local Government Act-2013. Retrieved from https:pdfs.lgkp.gov.pk > wpcontent $>$ uploads > 2013/12 > Local-Government-Act-

Koyuncu, B. \& Sumbas, A. (2016). Discussing Women's Representation in Local Politics in Turkey: The Case of Female Mayorship. In Women's Studies International Forum, vol.58, pp.41-50.

Krook, M. L. (2010). Quotas for Women in Politics: Gender and Candidate Selection Reform worldwide. Oxford University Press. Retrieved on June, 2019 from https://www.oxfordscholarship.com > acprof:oso > acprof-9780195375671

Naz, A. \& Ahmad, W. (2012). Socio-Cultural Impediments to Women Political Empowerment in Pakhtun Society. Academic Research International, vol.3:1, p.163.

Naz, A. \& Chaudhry, H. U. R. (2011). Gender and Development: Socio-Cultural, Economic, Religious and Political Impediments in Women's Empowerment and Gender Development: A Case Study of Malakand Division KPK Pakistan. BIOINFO Sociology, vol.1:1, pp.15-24.

Nazneen, S. (2018). Gender and Intersecting Inequalities in Local Government in South Asia. Retrieved on July, 2019 from https://opendocs.ids.ac.uk > opendocs > handle

Ngara, C. O. \& Ayabam, A. T. (2013). Women in Politics and Decision-Making in Nigeria: Challenges and Prospects. European Journal of Business and Social Sciences, vol.2:8, pp.47-58.

Ocran, R. K. (2014). Women's Political Participation: A Comparative Study on Ghana and Tanzania. University of Eastern Finland. Retrieved from https://pdfs. epublications.uef.fi > pub > urn_nbn_fi_uef-20140924 
Ormston, R., Spencer, L., Barnard, M. \& Snape, D. (2014). The Foundations of Qualitative Research. Qualitative Research Practice: A Guide for Social Science Students and Researchers, vol.2, pp.52-55.

Paxton, P., Hughes, M. \& Green, J. (2006). The International Women's Movement and Women's Political Representation, 1893-2003. American Sociological Review, vol.71:6, pp.898-920. Retrieved from http://www.jstor.org/stable/25472436

Reyes, S. L. \& Azizah, W. (2002). Quotas for Women for Legislative Seats at the Local Level in Pakistan. Perempuan di Parlemen: Bukan Sekedar Jumlah. Retrieved from https://iknowpolitics.org > sites > default > files > cs_pakistan_reynes

Saeed, M., Ullah, M. \& Alam, H. (2019). Women's Perceptions of Factors Barring their Political Participation in Khyber Pakhtunkhwa: A Case Study of District Dir Upper. Pakistan Journal of Women's Studies, vol.26:1.

Shah, I. A., Aziz, A. \& Ahmad, M. S. (2015). Women Councillors for Women's Empowerment in Pakistan. Journal of International Women's Studies, vol.16:3, p.203.

Shvedova, N. (2005). Obstacles to Women's Participation in Parliament. Women in Parliament: Beyond Numbers, vol.33, pp.22-45.

Teddlie, C. \& Yu, F. (2007). Mixed Methods Sampling: A Typology with Examples. Journal of Mixed Methods Research, vol.1:1, pp.77-100.

Tefera, A. A. (2010). Women Representation in Parliament: Comparative Analysis: Special Emphasis Given to South Africa and Ethiopia. Unpublished Master's Thesis). The Central European University, Hungary. Retrieved from https://pdfs. www.etd.ceu.hu > tefera_awotash

Umer, S., Othman, Z. \& Hassan, K. B. H. (2016). Socio-Cultural Obstacles to Women's Participation in Politics, In Rural Areas of Balochistan, Pakistan. International Journal of Business and Social Science, vol.7:10, pp.145-152.

United Nations (1995). Beijing Declaration and Platform for Action. Retrieved from https://www.un.org/en/events/pastevents/pdfs/Beijing_Declaration_and_Platform _for_Action.pdf 
UNDP (2005). Regional Organizations, Gender Equality and the Political Empowerment of Women. Retrieved on April 01, 2019 from https://www.undp.org > dam > undp > library > Inclusive Political Processes

Yuval-Davis, N. (2006). Intersectionality and Feminist Politics. European Journal of Women's Studies, vol.13:3, pp.193-209.

Zakar, R., Zakar, M. Z. \& Hamid, N. (2018). Gender Mainstreaming in Politics: Perspective of Female Politician from Pakistan. Asian Journal of Women's Studies, vol.24:2, pp.224-245.

Latif Ullah is Ph.D Scholar in the Department of Sociology, Institute of Social \& Cultural Studies, University of Punjab, Lahore, Pakistan.

Khalil Ahmad is an Associate Professor in the Department of Sociology, Institute of Social \& Cultural Studies, University of Punjab, Lahore, Pakistan. 